\title{
Congenital Stationary Night Blindness Type 2 Mutations S229P, G369D, L1068P, and W1440X Alter Channel Gating or Functional Expression of $\mathrm{Ca}_{\mathrm{v}} 1.4 \mathrm{~L}$-type $\mathrm{Ca}^{2+}$ Channels
}

\author{
Jean-Charles Hoda, ${ }^{1}$ Francesca Zaghetto, ${ }^{1,2}$ Alexandra Koschak, ${ }^{1}$ and Jörg Striessnig ${ }^{1}$ \\ ${ }^{1}$ Abteilung Pharmakologie und Toxikologie, Institut für Pharmazie, Universität Innsbruck, A-6020 Innsbruck, Austria, and ${ }^{2}$ Dipartimento di Farmacologia \\ e Anestesiologia, Università Degli Studi Di Padova, 35131 Padova, Italy
}

Mutations in the CACNA1F gene (voltage-dependent L-type calcium channel $\alpha 1 \mathrm{~F}$ subunit) encoding retinal Ca $1.4 \mathrm{~L}_{\mathrm{v}}$-type Ca ${ }^{2+}$ channels cause X-linked recessive congenital stationary night blindness type 2 (CSNB2). Many of them are predicted to yield nonfunctional channels. Complete loss of $\mathrm{Ca}_{\mathrm{v}} 1.4$ function is therefore regarded as a pathogenetic mechanism for the impaired signaling from photoreceptors to second-order retinal neurons. We investigated the functional consequences of CSNB2 missense mutations S229P, G369D, and L1068P and the C-terminal truncation mutant W1440X.

After expression in Xenopus laevis oocytes or human embryonic kidney tsA-201 cells, inward $\mathrm{Ca}^{2+}$ current $\left(I_{\mathrm{Ca}}\right)$ and inward $\mathrm{Ba}^{2+}$ current $\left(I_{\mathrm{Ba}}\right)$ could be recorded from mutations G369D and L1068P. G369D shifted the half-maximal voltage for channel activation $\left(V_{0.5, \text { act }}\right)$ significantly to more negative potentials $(>11 \mathrm{mV})$, slowed inactivation, and removed $\mathrm{Ca}^{2+}$-dependent inactivation. The L1068P mutant yielded currents only in the presence of the channel activator BayK8644. Currents $\left(I_{\mathrm{Ba}}\right)$ inactivated faster than wild type (WT) and recovered more slowly from inactivation $\left(I_{\mathrm{Ba}}\right.$ and $\left.I_{\mathrm{Ca}}\right)$. No channel activity could be measured for mutants S229P and W1440X after oocyte expression. No W1440X $\alpha 1$ protein was detected after expression in tsA-201 cells, whereas S229P (as well as G369D and L1068P) $\alpha 1$ subunits were expressed at levels indistinguishable from WT $(n=3)$.

Our data provide unequivocal evidence that CSNB2 missense mutations can induce severe changes in $\mathrm{Ca}_{\mathrm{v}} 1.4$ function, which may decrease (L1068P and S229P) or even increase (G369D) channel activity. The lower activation range of G369D can explain the reduced dynamic range of photoreceptor signaling. Moreover, we demonstrate that loss of channel function of one (L1068P) CSNB2 mutation can be rescued by a $\mathrm{Ca}^{2+}$ channel activator.

Key words: voltage-gated $\mathrm{Ca}^{2+}$ channels; congenital stationary night blindness; missense mutations; genetic diseases; sensory cells; channelopathies

\section{Introduction}

Different types of voltage-gated $\mathrm{Ca}^{2+}$ channels mediate depolarization-induced $\mathrm{Ca}^{2+}$ entry into electrically excitable cells (Catterall, 2000). $\mathrm{Ca}_{\mathrm{v}} 2 \mathrm{Ca}^{2+}$ channels targeted to the neurotransmitter release sites at nerve terminals (Zamponi, 2003) control fast (phasic) neurotransmitter release in neurons (Wheeler et al., 1994). In contrast, $\mathrm{Ca}_{\mathrm{v}} 1 \mathrm{~L}$-type $\mathrm{Ca}^{2+}$ channels (LTCCs) mediate tonic neurotransmitter release in sensory cells such as cochlear inner hair cells and the retina. In cochlear inner hair cells, L-type currents are formed exclusively by $\mathrm{Ca}_{\mathrm{v}} 1.3$ (Platzer et al., 2000). In photoreceptors and bipolar cells, $\mathrm{Ca}_{\mathrm{v}} 1.3$ and $\mathrm{Ca}_{\mathrm{v}} 1.4$ exist (Morgans et al., 2001; Ball et al., 2002; Barnes and

Received July 27, 2004; revised 0ct. 20, 2004; accepted Nov. 8, 2004.

This work was supported by Grant P-17109 from the Fonds zur Förderung der Wissenschaftlichen Forschung (J.S.), the Österreichische Nationalbank, and Grant HPRN-CT-2000-00082 from the European Community. We thank G. Pelster and J. Aldrian for excellent technical support and M. J. Sinnegger-Brauns and 0. Strauss for helpful comments on this manuscript.

Correspondence should be addressed to Jörg Striessnig, Department of Pharmacology and Toxicology, University of Innsbruck, Peter-Mayrstrasse 1//, A-6020 Innsbruck, Austria. E-mail: joerg.striessnig@uibk.ac.at.

DOI:10.1523/JNEUROSCI.3054-04.2005

Copyright $\odot 2005$ Society for Neuroscience $\quad$ 0270-6474/05/250252-08\$15.00/0
Kelly, 2002; McRory et al., 2004), but their relative contribution to total $\mathrm{Ca}^{2+}$ influx and the visual process remains unclear. Photoreceptors depolarize from a resting potential of approximately $-55 \mathrm{mV}$ during a light stimulus (Witkovsky et al., 1997) to approximately $-40 \mathrm{mV}$ in the dark, thus eliciting depolarizationinduced $\mathrm{Ca}^{2+}$ influx through LTCCs (Corey et al., 1984; Witkovsky et al., 1997; Schneeweis and Schnapf, 2000; Moriondo et al., 2001). This triggers tonic glutamate release from the photoreceptor terminals (Morgans, 2000). $\mathrm{Ca}_{\mathrm{v}} 1.3$ and $\mathrm{Ca}_{\mathrm{v}} 1.4$ LTCCs are especially suited for supporting tonic $\mathrm{Ca}^{2+}$ influx, because they inactivate incompletely during maintained depolarizations and activate quickly at voltages below $-40 \mathrm{mV}$ (Koschak et al., 2003; Baumann et al., 2004; McRory et al., 2004).

$\mathrm{Ca}_{\mathrm{v}} 1.4 \alpha 1$ subunits predominantly occur in retinal neurons but were also detected in dorsal root ganglia (Murakami et al., 2001), lymphatic organs, and immune cells (McRory et al., 2004). Their contribution to retinal function is evident from mutations in the $\mathrm{Ca}_{\mathrm{v}} 1.4$ gene [CACNA1F (voltage-dependent L-type calcium channel $\alpha 1 \mathrm{~F}$ subunit)], which cause X-linked congenital stationary night blindness type 2 (CSNB2) (Bech-Hansen et al., 1998; Strom et al., 1998). The term is misleading, because night 
blindness may not be the major complaint. Typical CSNB2 symptoms are moderately low visual acuity, myopia, nystagmus, and variable levels of night blindness, but one or more of these symptoms may be absent (Boycott et al., 2000). The eye fundus is normal, but electroretinograms are severely abnormal, with changes indicating a defect in neurotransmission between photoreceptors and second-order neurons (Tremblay et al., 1995).

Most of the $>40$ structural CACNA1F aberrations cause severe structural changes, such as truncated $\alpha 1$ subunits, unlikely to support significant channel activity. In the absence of a functional allele in affected males, this implies that CSNB2 can result from a complete loss of $\mathrm{Ca}_{\mathrm{v}} 1.4$ channel function. This is in contrast to a recent finding that some single missense mutations do not alter channel function after expression in mammalian cells (McRory et al., 2004).

In this study, we present a detailed biophysical analysis of three CSNB2 missense mutations and a C-terminal truncation mutant. Our data provide convincing evidence that all of them result in profound changes of $\mathrm{Ca}_{\mathrm{v}} 1.4$ channel gating or functional channel expression. We also show that CSNB2 mutations can lead to increased LTCC function, suggesting that both gain and loss of LTCC function must be able to hamper photoreceptor signaling to second-order retinal neurons.

\section{Materials and Methods}

\section{$C a_{v} 1.4 \mathrm{cDNA}$ mutants}

Mutations were introduced into the $\mathrm{Ca}_{\mathrm{v}} 1.4 \alpha 1 \mathrm{cDNA}$ (Strom et al., 1998) cloned previously from human retina (Koschak et al., 2003) (GenBank accession number NM_005153; open reading frame length, 5898 bp). Nucleotide positions of endonuclease restriction sites are given in parentheses.

Mutants were constructed by applying the "geneSOEing" technique (Horton et al., 1989). For heterologous expression in Xenopus laevis oocytes, $\mathrm{Ca}_{\mathrm{v}} 1.4$ cDNA together with the polyadenylation sequence of pNKS2 plasmid (a gift from O. Pongs, ZMNH, Hamburg, Germany) was cloned into the NheI-XbaI polylinker sites of the expression vector pCIneo by coligating $\mathrm{Ca}_{\mathrm{v}} 1.4 \mathrm{cDNA}$ (NheI-SmaI) and the polyadenylation sequence ( $S m a \mathrm{I}-\mathrm{Xba \textrm {I }})$.

Mutants S229P (SP) and G369D (GD) were constructed by using an NheI-AgeI ( -12-1390) cassette subsequently ligated into the NheI-AgeI (-12-1390)-cut Ca $1.4 \alpha 1-$ pCIneo construct. Mutant L1068P (LP) was cloned using a Bst1107I-EcoRI (3105-4348) cassette, respectively.

For the construction of the truncated mutant W1440X (WX), a termination codon was introduced by PCR. The AgeI-EcoRI-cut PCR fragment was ligated into the AgeI-EcoRI (1390-4348)-cut $\mathrm{Ca}_{\mathrm{v}} 1.4 \alpha 1-$ pCIneo cDNA. The integrity of all of the constructs was confirmed by DNA sequencing (MWG Biotech, Ebersberg, Germany).

\section{Transient expression of $\mathrm{Ca}_{v} 1.4$ mutants in mammalian cells}

For patch-clamp recordings, human embryonic kidney tsA-201 cells were transfected with human $\mathrm{Ca}_{\mathrm{v}} 1.4$ wild-type (WT) $\alpha 1$, mutant GD, or mutant LP $\alpha 1$ subunit cDNA together with $\beta 3$ (Castellano et al., 1993) and $\alpha 2 \delta 1$ (Ellis et al., 1988) auxiliary subunits, as described previously in our first characterization of $\mathrm{Ca}_{\mathrm{v}} 1.4$ (Koschak et al., 2003). For immunoblotting, membranes from tsA-201 cells transfected with $3 \mu \mathrm{g}$ of $\alpha 1,2 \mu \mathrm{g}$ of $\beta 3$, and $2.5 \mu \mathrm{g}$ of $\alpha 2 \delta 1$ subunit cDNA, and $2.5 \mu \mathrm{g}$ of pUC18 carrier DNA in $10 \mathrm{~cm}$ culture dishes were prepared as described previously (Huber et al., 2000). Immunoblotting was performed as described previously using a generic anti- $\alpha 1$ sequence-directed antibody (raised against a synthetic peptide corresponding to residues 1382-1400 of the $\mathrm{Ca}_{\mathrm{v}} 1.1 \alpha 1$ subunit) (Safayhi et al., 1997).

Expression of $\mathrm{Ca}_{v} 1.4$ mutants in X. laevis oocytes Capped runoff poly $\left(\mathrm{A}^{+}\right) \mathrm{cRNA}$ transcripts from XbaI-linearized cDNA templates were synthesized according to the protocol of Krieg and Melton (1984) (using T7 polymerase). cRNA encoding wild-type or mutant $\mathrm{Ca}_{\mathrm{v}} 1.4 \alpha 1$ subunits were mixed at equimolar concentrations with auxil- iary subunits $\beta 2 \mathrm{a}$ (Perez-Reyes et al., 1992) or $\beta 3$ (Castellano et al., 1993) and $\alpha 2 \delta 1$ (Ellis et al., 1988). Fifty nanoliters of this cRNA mixture (0.1$0.33 \mathrm{pmol} / \mu \mathrm{l}$ ) was injected using a Microdispenser (Drummond Scientific, Bromall, PA) into freshly isolated and defolliculated stages V and VI $X$. laevis oocytes. Currents were measured $4-7 \mathrm{~d}$ after injection. Microinjected oocytes were kept at $19^{\circ} \mathrm{C}$ in a sterile ND96 medium (in mм: 96 $\mathrm{NaCl}, 2 \mathrm{KCl}, 1 \mathrm{MgCl}_{2}, 5 \mathrm{HEPES}$, and $1.8 \mathrm{CaCl}_{2}$, adjusted to $\mathrm{pH} 7.5$ with $\mathrm{NaOH}$ ) and supplemented with $100 \mathrm{U} / \mathrm{ml}$ penicillin and $100 \mu \mathrm{g} / \mathrm{ml}$ streptomycin (Sigma, St. Louis, MO).

\section{Electrophysiological recordings}

$\mathrm{X}$. laevis oocytes. Four to $7 \mathrm{~d}$ after cRNA injection, inward $\mathrm{Ba}^{2+}$ current $\left(I_{\mathrm{Ba}}\right)$ or inward $\mathrm{Ca}^{2+}$ current $\left(I_{\mathrm{Ca}}\right)$ was measured at $21-23^{\circ} \mathrm{C}$ by a twomicroelectrode voltage clamp using an oocyte clamp NPI Electronic (Tamm, Germany) amplifier connected through an Axon Instruments (Union City, CA) digidata 1322A analog-to-digital board and interfaced to a personal computer.

Before recording $I_{\mathrm{Ba}}$ or $I_{\mathrm{Ca}}$, oocytes were injected with $30 \mathrm{nl}$ of $100 \mathrm{~mm}$ BAPTA solution, $\mathrm{pH} 7.4$, to prevent contamination by $\mathrm{Ca}^{2+}$-activated $\mathrm{Cl}^{-}$and $\mathrm{K}^{+}$conductances. To exclude the possibility that the slowly inactivating $\mathrm{Ca}_{\mathrm{v}} 1.4$ currents were contaminated by $\mathrm{Ca}^{2+}$ - or $\mathrm{Ba}^{2+}$ activated $\mathrm{Cl}^{-}$currents despite injection of BAPTA, we tested the effect of $70 \mathrm{~mm}$ extracellular chloride, which must result in $\mathrm{Cl}^{-}$inward currents mimicking faster LTCC inactivation. Such changes were present without intracellular $\mathrm{Ca}^{2+}$ buffering but were not observed after BAPTA injection for BayK8644 (BayK)-stimulated $\mathrm{Ca}_{\mathrm{v}} 1.4(n>4)$ or slowly inactivating $\mathrm{Ca}_{\mathrm{v}} 1.2$ currents (coexpressed with $\beta 2 \mathrm{a}$ and $\alpha 2 \delta 1 ; n>8$; data not shown). Similarly, no evidence for contamination by (inward) $\mathrm{K}^{+}$current was observed after inclusion of $100 \mathrm{~mm} \mathrm{~K}^{+}$in the bath $(n>4$; data not shown).

As a control, endogenous $I_{\mathrm{Ba}}$ was measured from oocytes injected only with $\beta 3$ and $\alpha 2 \delta 1$ auxiliary subunits. $I_{\mathrm{Ba}}$ and $I_{\mathrm{Ca}}$ were recorded only from oocytes in which $I_{\mathrm{Ba}}$ and $I_{\mathrm{Ca}}$ exceeded the highest endogenous currents in the same oocyte batch by at least fourfold to fivefold $(0.25 \mathrm{nA})$. Currents larger than $1.2 \mu \mathrm{A}$ were not included in the analysis. Data analysis and acquisition were performed by using the pClamp software package (version 9.0; Axon Instruments). Microelectrodes were filled with $2.8 \mathrm{M} \mathrm{CsCl}$, $0.2 \mathrm{M} \mathrm{CsOH}, 10 \mathrm{~mm}$ EGTA, and $10 \mathrm{~mm}$ HEPES, adjusted to $\mathrm{pH} 7.4$ with $\mathrm{HCl}$, and had resistances of $0.1-1.2 \mathrm{M} \Omega$.

During $I_{\mathrm{Ba}}$ recordings, oocytes were perfused with a solution containing the following (in $\mathrm{mm}$ ): $10 \mathrm{Ba}(\mathrm{OH})_{2}, 50 \mathrm{Na}(\mathrm{OH}), 2 \mathrm{CsOH}$, and 5 HEPES, adjusted to $\mathrm{pH} 7.4$ with methanesulfonic acid. To obtain $I_{\mathrm{Ca}}$, the bath solution was switched to a solution containing $\mathrm{Ca}\left(\mathrm{NO}_{3}\right)_{2}$ instead of $\mathrm{Ba}(\mathrm{OH})_{2}$.

Leak correction was performed by adjusting the current traces by a factor calculated from the difference between the leak at -80 and -90 $\mathrm{mV}$, respectively. Voltage dependence of activation was determined from $I-V$ curves obtained by step depolarizations from a holding potential of $-80 \mathrm{mV}$ to different test potentials. The half-maximal voltage for channel activation $\left(V_{0.5 \text {,act }}\right)$, the slope factor of the curve at $V_{0.5 \text {,act }}\left(k_{\text {act }}\right)$, the maximal slope conductance $(G)$, and the reversal potential were obtained by fitting the data to the Boltzmann equation (Koschak et al., 2003).

Inactivation was determined by applying a $10 \mathrm{sec}$ depolarizing pulse from a holding potential of $-80 \mathrm{mV}$ to a test potential $10 \mathrm{mV}$ positive to the maximum of the current-voltage relationship $\left(V_{\max }\right)$ estimated from the $I-V$ relationship.

Recovery from inactivation was studied using a multipulse protocol. After a $10 \mathrm{sec}$ depolarizing pulse to $V_{\max }$ plus $10 \mathrm{mV}$ from a holding potential of $-80 \mathrm{mV}$, the time course of $I_{\mathrm{Ba}}$ recovery was determined by applying 50 msec test pulses to the same potential at $0.5,1,2,5$, and $10 \mathrm{sec}$ after the prepulse.

tsA-201 cells. Whole-cell patch-clamp experiments were performed as described by us previously (Koschak et al., 2003) using $15 \mathrm{~mm} \mathrm{Ba}^{2+}$ as a charge carrier.

\section{Statistical analysis}

Data were analyzed using the pClamp software package (version 9.0; Axon Instruments). Origin (OriginLab, Northampton, MA) and Graph- 
Pad Prism 4 software (GraphPad Software, San Diego, CA) were used for nonlinear curve fitting and statistical data analysis. All data are given as means $\pm \mathrm{SE}$ for the indicated number of experiments. Statistical significance was determined by unpaired Student's $t$ test and oneway ANOVA, followed by the Bonferroni multiple-comparison test as indicated.

\section{Results}

We introduced three CSNB2 missense mutations, SP, GD, and LP, into $\mathrm{Ca}_{\mathrm{v}} 1.4 \alpha 1$ subunits. As illustrated in Figure 1, mutation GD is located at the end of IS6, LP in the pore-forming S5-S6 linker of repeat III, and SP within the IS4-IS5 linker (Fig. 1). SP aligns with residue $\mathrm{S} 218$ of $\mathrm{Ca}_{\mathrm{v}} 2.1$ channels, which has been found to cause a severe form of familial hemiplegic migraine type 1 (FHM1) (with delayed cerebral edema and coma after minor head trauma) (Kors et al., 2001). We also constructed mutation WX, which causes a truncation of most of the C-terminal tail (Fig. 1). All of these mutations concern highly conserved amino acids, as shown in sequence alignments with other L-type and non-L-type $\left(\mathrm{Ca}_{\mathrm{v}} 2.1\right) \mathrm{Ca}^{2+}$ channels in Figure 1.

We have shown recently that only a small fraction $(22 \%)$ of tsA-201 cells successfully transfected with $\mathrm{Ca}_{\mathrm{v}} 1.4 \mathrm{Ca}^{2+}$ channels also express measurable currents (Koschak et al., 2003). This low-expression yield complicated a detailed electrophysiological analysis in this expression system. For routine analysis of channel mutants, we therefore expressed $\mathrm{Ca}_{\mathrm{v}} 1.4$ channels in $X$. laevis oocytes, which gave robust expression 3-6 d after cRNA injection. Because previous studies have shown that $\mathrm{Ca}_{\mathrm{v}} 1.4$ current-gating properties are only minimally affected by $\beta$ subunit isoforms (Koschak et al., 2003; McRory et al., 2004), we coexpressed $\mathrm{Ca}_{\mathrm{v}} 1.4 \alpha 1$ together with $\alpha 2 \delta 1$ and $\beta 3$ subunits, which resulted in higher currents than $\alpha 2 \delta 1$ plus $\beta 2 \mathrm{a}$ in $X$. laevis oocytes ( $n=20$; data not shown). To further increase current amplitudes (especially of smaller $I_{\mathrm{Ca}}$; see below), most recordings were performed in the presence of $10 \mu \mathrm{M}$ BayK, but data without BayK were also obtained when appropriate.

In oocytes, WT channels mediated $I_{\mathrm{Ba}}$ with characteristics very similar to tsA-201 cell-expressed currents (Koschak et al., 2003; Baumann et al., 2004; McRory et al., 2004). With $10 \mathrm{~mm}$ $\mathrm{Ba}^{2+}$ as charge carrier, $V_{0.5 \text {,act }}$ was -12.8 and $-17.7 \mathrm{mV}$ in the absence and presence of $10 \mu \mathrm{M}$ BayK, respectively $(n=20-35)$ (Table 1; Fig. $2 A, B$ ). During a $10 \mathrm{sec}$ depolarization to the maximum of the $I-V$ curve, $36.6 \pm 0.84 \%(n=23)$ of $I_{\mathrm{Ba}}$ was inactivated (Fig. $3 A-D$ ). When $\mathrm{Ba}^{2+}$ was replaced by $\mathrm{Ca}^{2+}$ as the charge carrier, the fraction of current inactivating during a $10 \mathrm{sec}$ pulse increased significantly $(51.8 \pm 1.46 \% ; n=19 ; p<0.001)$, indicating the presence of $\mathrm{Ca}^{2+}$-dependent inactivation (CDI) under our experimental conditions (Fig. $3 A-D$ ). Because CDI is absent under conditions of strong intracellular $\mathrm{Ca}^{2+}$ buffering (Koschak et al., 2003) in tsA-201 cells, it is possible that $\mathrm{Ca}^{2+}$ buffering at the cytoplasmic side of the channel is weaker in oocytes despite injection of $30 \mathrm{nl}$ of $100 \mathrm{~mm}$ BAPTA (see Materials and Methods). This would permit a form of CDI that can only occur with weak intracellular $\mathrm{Ca}^{2+}$ buffering as observed, for example, for $\mathrm{Ca}_{\mathrm{v}} 2.1$ (P- and Q-type channels) (Liang et al., 2003). We therefore used $\mathrm{Ca}_{\mathrm{v}} 2.1$ to test our hypothesis. Replacement of $\mathrm{Ba}^{2+}$ by $\mathrm{Ca}^{2+}$ in the perfusing solution significantly increased the inactivation of $\mathrm{Ca}_{\mathrm{v}} 2.1$ currents from $39.8 \pm 1.4$ to $82.3 \pm$ $3.8 \%(n=4)$ during $10 \mathrm{sec}$ pulses to $V_{\text {max }}$. The possibility that the slowly inactivating $\mathrm{Ca}_{\mathrm{v}} 1.4$ currents were contaminated by $\mathrm{Ca}^{2+}$ or $\mathrm{Ba}^{2+}$-activated $\mathrm{Cl}^{-}$or $\mathrm{K}^{+}$currents despite intracellular BAPTA injection could be excluded in experiments with $70 \mathrm{~mm}$ $\mathrm{Cl}^{-}$or $100 \mathrm{mM} \mathrm{K}^{+}$in the bath (see Materials and Methods). Thus, the CDI behavior of $\mathrm{Ca}_{\mathrm{v}} 1.4$ resembles more closely the calmodulin N-lobe-mediated CDI of non-LTCCs rather than the calmodulin C-lobe-mediated CDI of LTCCs (Koschak et al., 2003; Liang et al., 2003; McRory et al., 2004).

Subsequently, we investigated whether mutants SP, GD, LP, and WX form functional channels in X. laevis oocytes. Mutant GD supported $I_{\mathrm{Ba}}$ and $I_{\mathrm{Ca}}$ with amplitudes comparable with WT in both the absence and presence of $10 \mu \mathrm{M}$ BayK (Fig. 2, Table 1). In contrast, mutant LP never yielded $I_{\mathrm{Ba}}$ exceeding the endogenous current (Fig. 2C), but large currents were obtained after perfusing the same oocyte with $10 \mu \mathrm{M}$ BayK (Fig. 2C). Mutants SP and WX did not mediate $I_{\mathrm{Ba}}$, exceeding endogenous currents in six (SP) and four (WX) different pools of oocytes injected with different amounts of cRNA and recordings up to $7 \mathrm{~d}$ after injection.

Mutation GD caused profound changes in $\mathrm{Ca}_{\mathrm{v}} 1.4$ channel characteristics. It significantly shifted the $V_{0.5 \text {,act }}$ of $I_{\mathrm{Ba}}$ to more negative potentials by $>13 \mathrm{mV}$ in the absence and presence of BayK (Fig. 2A; Table 1). This shift was even larger for $I_{\mathrm{Ca}}(>20$ $\mathrm{mV}$ ) (Fig. 2B; Table 1) and remained when subgroups with different current amplitudes $(0.30-0.59$ vs $0.60-1.0 \mu \mathrm{A})$ were analyzed (data not shown). The GD mutation increased the time-topeak current (Fig. 3A, inset) and strongly reduced current inactivation during $10 \mathrm{sec}$ depolarizing pulses to $V_{\max }$ for both $I_{\mathrm{Ba}}$ 


\begin{tabular}{|c|c|c|c|}
\hline & WT & GD & $\mathrm{LP}$ \\
\hline \multicolumn{4}{|l|}{$V_{0.5 \mathrm{act}}(\mathrm{mV})$} \\
\hline $10 \mathrm{mmBa}^{2+}$ & $-12.8 \pm 0.5 ; n=20$ & $-26.5 \pm 1.0^{* * *} ; n=16$ & ND \\
\hline $10 \mathrm{mmBa}^{2+}+$ BayK & $-17.7 \pm 0.5 ; n=35$ & $-35.4 \pm 1.0^{* * *} ; n=14$ & $-18.6 \pm 0.5 ; n=12$ \\
\hline $10 \mathrm{mmCa}^{2+}+$ BayK & $-10.3 \pm 0.5 ; n=30$ & $-31.8 \pm 1.1^{* * *} ; n=8$ & $-15.1 \pm 0.8^{* * *} ; n=15$ \\
\hline \multicolumn{4}{|l|}{ Activation threshold (mV) } \\
\hline $10 \mathrm{~mm} \mathrm{Ba}^{2+}$ & $-24.6 \pm 0.4 ; n=20$ & $-39.4 \pm 1.0^{* * *} ; n=16$ & ND \\
\hline $10 \mathrm{mmBa}^{2+}+$ BayK & $-28.7 \pm 0.5 ; n=35$ & $-45.9 \pm 1.2^{* * *} ; n=14$ & $-28.6 \pm 0.4 ; n=12$ \\
\hline $10 \mathrm{mmCa}^{2+}+$ BayK & $-24.0 \pm 0.5 ; n=30$ & $-43.2 \pm 1.3^{* * *} ; n=8$ & $-27.5 \pm 0.7^{* * *} ; n=15$ \\
\hline \multicolumn{4}{|l|}{$k_{\text {act }}$} \\
\hline $10 \mathrm{mmBa}^{2+}$ & $-4.7 \pm 0.1 ; n=20$ & $-4.7 \pm 0.2 ; n=16$ & ND \\
\hline $10 \mathrm{mmBa}^{2+}+$ BayK & $-3.9 \pm 0.1 ; n=35$ & $-4.2 \pm 0.3 ; n=14$ & $-3.8 \pm 0.2 ; n=12$ \\
\hline $10 \mathrm{mmCa}^{2+}+$ Bayk & $-5.0 \pm 0.2 ; n=30$ & $-4.0 \pm 0.2^{* *} ; n=8$ & $-4.3 \pm 0.2^{*} ; n=15$ \\
\hline \multicolumn{4}{|l|}{ Reversal potential (mV) } \\
\hline $10 \mathrm{mmBa}^{2+}$ & $50.6 \pm 0.5 ; n=20$ & $44.7 \pm 0.9^{* * *} ; n=16$ & ND \\
\hline $10 \mathrm{mmBa}^{2+}+$ BayK & $46.9 \pm 0.4 ; n=35$ & $44.4 \pm 1.3^{*} ; n=14$ & $46.4 \pm 0.9 ; n=12$ \\
\hline $10 \mathrm{mmCa}^{2+}+$ BayK & $53.6 \pm 1.3 ; n=30$ & $45.3 \pm 1.1^{* *} ; n=8$ & $52.6 \pm 1.5 ; n=15$ \\
\hline \multicolumn{4}{|l|}{$I_{\mathrm{Ba}}$ versus $I_{\mathrm{Ca}}$} \\
\hline$G_{\mathrm{Ba}}(\mathrm{mS})$ & $12.7 \pm 0.7 ; n=35$ & $10.0 \pm 1.3 ; n=14$ & $11.1 \pm 1.2 ; n=12$ \\
\hline$G_{C a}(m S)$ & $11.1 \pm 0.8 ; n=30$ & $11.0 \pm 1.4 ; n=8$ & $13.0 \pm 1.2 ; n=15$ \\
\hline Percentage change (same 0ocyte) & $35.7 \pm 2.8 ; n=24$ & $-33.9 \pm 8.9^{* * *} ; n=6$ & $8.8 \pm 5.9 * * * ; n=7$ \\
\hline
\end{tabular}

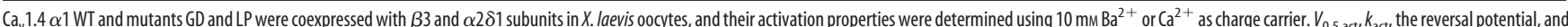
$G$ (maximal slope conductance) were obtained by fitting the data to the Boltzmann equation, as described in Materials and Methods. The activation threshold was determined as the test potential at which $5 \%$ of the maximal current was activated. Data are given as mean $\pm \mathrm{SE}$; ND, not determined. Note that the shift in $V_{0.5 \text {,act }}$ of GD and LP compared with WT could not be explained by currents with different amplitudes, because the differences persisted when smaller $(0.25-0.59 \mu \mathrm{A})$ or larger $(0.6-1.1 \mu \mathrm{A})$ currents were analyzed separately (data not shown). BayK, $10 \mu \mathrm{m}$ BayK present. Conductance was measured in the presence of $10 \mu \mathrm{m}$ BayK. Statistical differences for $V_{0.5}$ act, $k_{\text {act }}{ }^{\prime}$ activation thresholds, reversal potentials, and $G$ were calculated by one-way ANOVA, followed by the Bonferroni multiple-comparison test or by Student's $t$ test when appropriate. ${ }^{*} p<0.05,{ }^{* * *} p<0.01,{ }^{* * *} p<0.001$ versus WT.

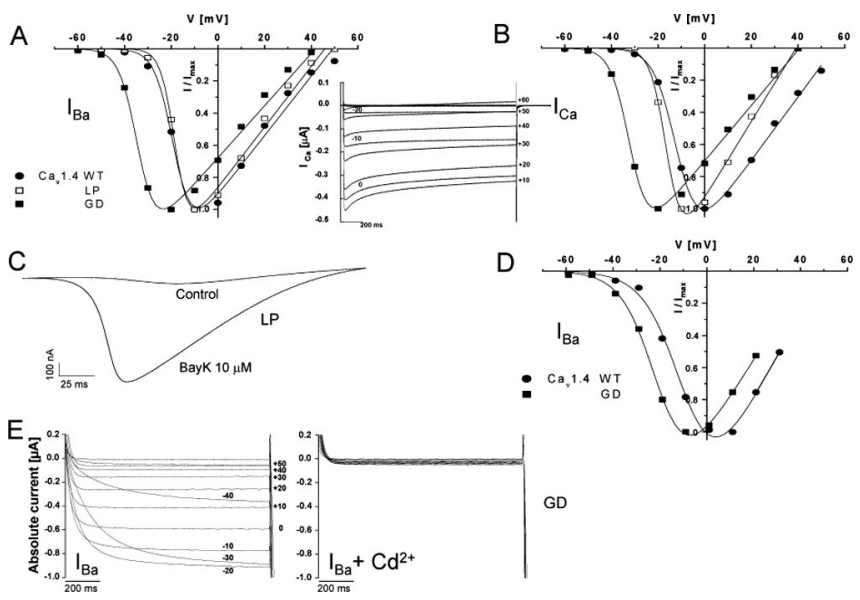

Figure 2. Activation properties of $\mathrm{Ca}_{\mathrm{v}} 1.4 \mathrm{WT}$ and mutant $\alpha 1$ subunits. $A, B$, Normalized $I-V$ curves for $\mathrm{Ca}_{\mathrm{v}} 1.4$ WT and mutants GD and $\mathrm{LP} \alpha 1$ subunits coexpressed with $\beta 3$ and $\alpha 2 \delta 1$ subunits in $X$. laevis oocytes. $\mathrm{Ba}^{2+}(A)$ or $\mathrm{Ca}^{2+}(B)$ were used as charge carriers with $10 \mu \mathrm{m}$ BayK present in the bath. Representative $/-V$ relationships are shown. For statistics, see Table 1. $B$, Inset, A representative original trace $(n>3)$ of $\mathrm{Ca}_{v} 1.4$ WT $\mathrm{Ca}^{2+}$ currents elicited by depolarizing pulses of $2 \mathrm{sec}$ from -80 to $+60 \mathrm{mV}$. C, Voltage ramps applied from a holding potential of $-80 \mathrm{to}+70 \mathrm{mV}$ within $360 \mathrm{msec}$ in the absence (control) and presence of $10 \mu \mathrm{m}$ BayK in the same mutant $L P$-expressing 00 cyte. Such a BayK requirement for $L P$ function was observed in all of the experiments $(n=18)$. A representative experiment is shown. $D$, Normalized $I-V$ curves for $\mathrm{Ca}_{\mathrm{v}} 1.4$ WT and mutant $\mathrm{GD} \alpha 1$ subunits coexpressed with $\beta 3$ and $\alpha 2 \delta 1$ subunits in tsA-201 cells (as described in Materials and Methods) using $15 \mathrm{~mm} \mathrm{Ba}^{2+}$ as charge carrier. Data points are means $\pm \mathrm{SE}\left(n=40\right.$ for WT and $n=6$ for GD). E, Representative family of mutant GD Ba ${ }^{2+}$ currents elicited by $1 \mathrm{sec}$ depolarizations from $-80 \mathrm{to}+60 \mathrm{mV}$ before (left) and after (right) the addition of $1 \mathrm{~mm} \mathrm{Cd}{ }^{2+}$, which resulted in a total block of the current.

(Fig. $3 A, B$ ) and $I_{\mathrm{Ca}}$ (Fig. 3C,D). After $10 \mathrm{sec}$, only $10.0 \pm 1.5 \%$ of $I_{\mathrm{Ba}}(n=13 ; p<0.001 \mathrm{vs} \mathrm{WT})$ and $8.2 \pm 0.87 \%$ of $I_{\mathrm{Ca}}(n=12 ; p<$ 0.001 vs WT) inactivated, indicating the absence of CDI in this mutant.

The GD mutation introduces a negative charge on the cytoplasmic end of IS6, which is involved in the formation of the cytoplasmic end of the pore. Therefore, we investigated whether this mutation can alter the permeation properties of the channel. When switching from $\mathrm{Ba}^{2+}$ - to $\mathrm{Ca}^{2+}$-containing solutions in the same oocyte, the maximal slope conductance (Table 1) for $I_{\mathrm{Ca}}$ through WT channels always decreased significantly by $33.5 \pm$ $4.3 \%(n=12)$. This indicates a lower permeability of the channel for $\mathrm{Ca}^{2+}$ than for $\mathrm{Ba}^{2+}$, a typical property of L-type channels (Hess et al., 1986). In contrast to WT, the conductance for $\mathrm{Ca}^{2+}$ was always larger than for $\mathrm{Ba}^{2+}$ (increase by $33.9 \pm 8.9 \% ; n=6$; $p<0.001$ vs WT) in GD channels, suggesting a relative increase in the permeability of $\mathrm{Ca}^{2+}$ versus $\mathrm{Ba}^{2+}$. The apparent reversal potential was significantly shifted to more negative voltages (Table 1), indicating a decrease in the divalent cation selectivity (Yang et al., 1993) of the GD channel. Cadmium completely blocked WT and mutant GD currents. No significant outward currents were observed at test potentials close to the reversal potential for $I_{\mathrm{Ba}}$ $\left(n>3\right.$ experiments for WT and GD) or $I_{\mathrm{Ca}}(n>2$ experiments for WT and GD) (Fig. 2E).

The GD mutation was analyzed previously by McRory et al. (2004). They did not observe the same biophysical changes (see Discussion). We could rule out that the observed differences in $V_{0.5 \text {,act }}$ of WT and GD were attributable to voltage errors introduced by different current amplitudes of mutant GD and WT (Table 1). To further confirm our findings obtained in oocytes, we also expressed GD in tsA-201 cells. Figures $2 D$ and 3, $E$ and $F$, illustrate that similar biophysical changes were observed for GD channels in tsA-201 cells. As in oocytes, GD yielded maximal $I_{\mathrm{Ba}}$ amplitudes ( $I_{\mathrm{Ba}}$ current density, $\left.16.6 \pm 6.0 \mathrm{pA} / \mathrm{pF} ; n=6\right)$ comparable with WT $\left(21.3 \pm 5.7 ; n=40 ; 15 \mathrm{mM} \mathrm{Ba}^{2+}\right)$, shifted the activation of $I_{\mathrm{Ba}}$ by $\sim 11 \mathrm{mV}$ to more negative potentials (WT, $V_{0.5 \text {,act }},-9.01 \pm 0.76, n=40 ; \mathrm{GD}, V_{0.5 \text {,act }},-19.8 \pm 1.8, n=6$; $p<0.001$ ), increased the time-to-peak current (WT, $11.0 \pm 3.5$ msec, $n=4$; GD, $365.1 \pm 85.1 \mathrm{msec}, n=6 ; p<0.05)$, and slowed inactivation of $I_{\mathrm{Ba}}$ during $10 \mathrm{sec}$ depolarizations to $V_{\max }$ (WT, $68.6 \pm 2.4 \%, n=17$; GD, $46.5 \pm 8.1 \%, n=6 ; p<0.01)$.

For the LP mutant, significant current was only measurable in the presence of BayK in both X. laevis oocytes (Fig. 2C) and 
A

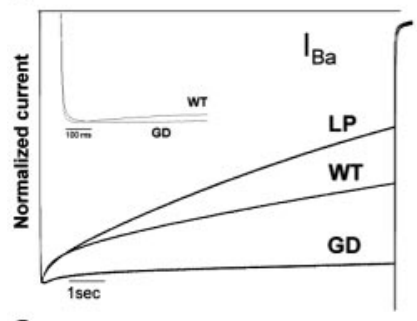

C

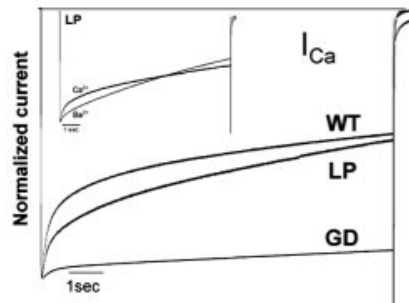

E

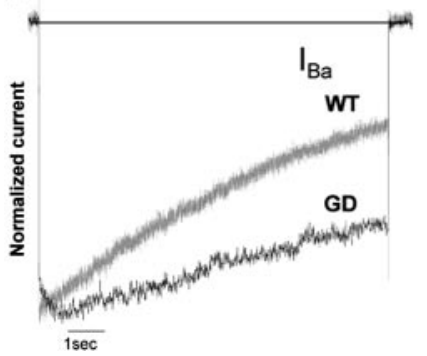

B

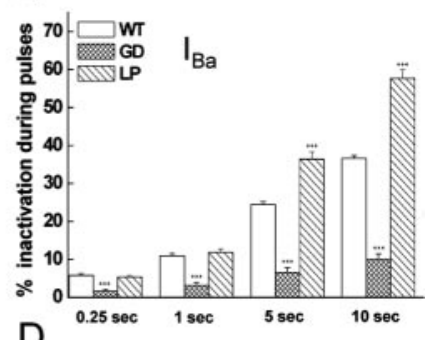

D

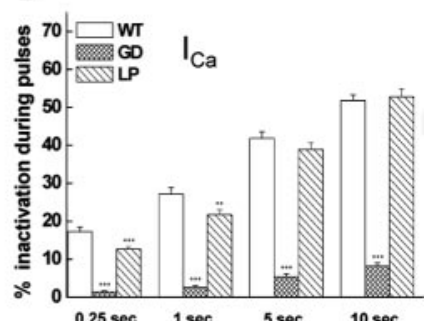

$F$

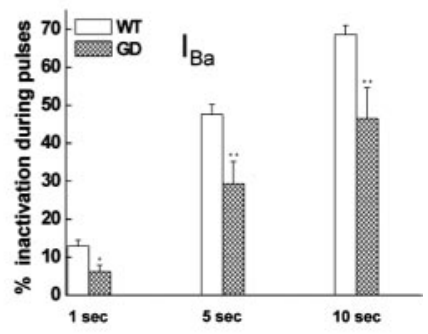

Figure 3. Inactivation properties of $\mathrm{Ca}_{\mathrm{v}} 1.4 \mathrm{WT}$ and mutant $\alpha 1$ subunits. $\mathrm{I}_{\mathrm{Ba}}(A, B)$ and $I_{\mathrm{Ca}}(C$, D) through $\mathrm{Ca}_{\mathrm{v}} 1.4$ WT and mutants GD and LP $\alpha 1$ subunits coexpressed with $\beta 3$ and $\alpha 2 \delta 1$ subunits in $X$. Iaevis 00 cytes were elicited by 10 sec depolarizing pulses from a holding potential of $-80 \mathrm{mV}$ to $V_{\text {max }}$ plus $10 \mathrm{mV}$ (10 $\mu \mathrm{m}$ BayK present). Traces were normalized to the peak current amplitudes. $A, C$, Representative current traces. $B, D$, Percentages of current inactivation were calculated after $0.25,1,5$, and 10 sec depolarizations to the voltage of peak current plus 10 $\mathrm{mV}$. Statistical differences for the percentage of inactivated current were determined by using one-way ANOVA, followed by the Bonferroni multiple-comparison test. Asterisks indicate statistically significant difference to WT $\left({ }^{* *} p<0.01 ;{ }^{* * *} p<0.001\right)$. GD increased the time-topeak current $(A$, inset; WT, $19.5 \pm 1.4 \mathrm{msec}, n=23 ; \mathrm{GD}, 68.9 \pm 13.3 \mathrm{msec}, n=13 ; p<$ 0.001). $B$, Inset, The complex inactivation time courses of $I_{\mathrm{Ba}}$ and $I_{\mathrm{Ca}}$ for mutant $L P . E, F, I_{\mathrm{Ba}}$ through $\mathrm{Ca}_{\mathrm{v}} 1.4$ WT and mutant GD $\alpha 1$ subunits coexpressed with $\beta 3$ and $\alpha 2 \delta 1$ subunits in tsA201 cells were elicited by 10 sec depolarizing pulses from a holding potential of $-90 \mathrm{mV}$ to $V_{\max }$. One representative experiment of six is shown. Currents were normalized to peak $I_{\mathrm{Ba}}$. Percentages of current inactivation $(F)$ were measured after 1,5 , and 10 sec depolarizations from $-90 \mathrm{mV}$ to the voltage of peak current. Asterisks indicate statistically significant difference $\left({ }^{*} p<0.05 ;{ }^{* *} p<0.01\right.$; unpaired Student's $t$ test $)$.

tsA-201 cells ( $I_{\mathrm{Ba}}$ current density, BayK absent, $0.86 \pm 0.089 \mathrm{pA} /$ $\mathrm{pF}, n=10$; BayK present, $17.6 \pm 9.2 \mathrm{pA} / \mathrm{pF}, n=6$ ). For $I_{\mathrm{Ca}}$, but not $I_{\mathrm{Ba}}$, a small but significant $4.8 \mathrm{mV}$ shift of $V_{0.5 \text {,act }}$ to more negative potentials was evident in X. laevis oocytes $(p<0.001)$ (Table 1). This significant difference remained when subgroups with different current amplitudes $(0.30-0.59$ vs $0.60-1.0 \mu \mathrm{A})$ were compared (data not shown). The amplitudes of $I_{\mathrm{Ba}}$ and $I_{\mathrm{Ca}}$ recorded in the same oocyte were similar (Table 1), indicating that this mutation also affects divalent cation permeability. For $\mathrm{Ba}^{2+}$ currents, the inactivation time course was significantly faster than for WT $(p<0.001)$, with $57.7 \pm 2.1 \%(n=18)$ inactivating during $10 \mathrm{sec}$ pulses (Fig. $3 A, B$ ). In contrast to $I_{\mathrm{Ba}}$, $I_{\mathrm{Ca}}$ inactivation of LP was similar to WT at the end of the $10 \mathrm{sec}$ depolarizing pulse, and LP even slowed the early phase of $I_{\mathrm{Ca}}$ inactivation (Fig. 3D).
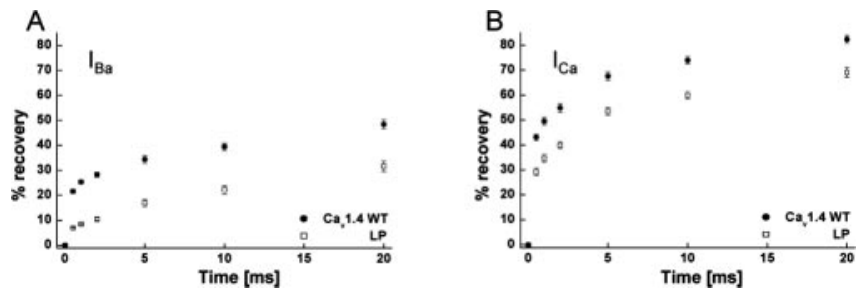

Figure 4. Recovery of inactivation of $\mathrm{Ca}_{\mathrm{v}} 1.4 \mathrm{WT}$ and mutant $\mathrm{LP} \alpha 1$ subunits. The percentage of recovery from the inactivated current was determined after $0.5,1,2,5,10$, and 20 sec after a 10 sec depolarization to $V_{\max }$ plus $10 \mathrm{mV}$ for $\mathrm{Ca}_{\mathrm{v}} 1.4$ WT and mutant $\mathrm{LP} \alpha 1$ subunits coexpressed with $\beta 3$ and $\alpha 2 \delta 1$ subunits in $X$. laevis oocytes. A concentration of $10 \mathrm{~mm} \mathrm{Ba}^{2+}(A)$ or $10 \mathrm{~mm}$ $\mathrm{Ca}^{2+}(B)$ was used as charge carriers (10 $\mu \mathrm{m}$ of BayK present). The extent of recovery was statistically significant after all of the time points indicated for $I_{\mathrm{Ba}}$ and $I_{\mathrm{Ca}}$ compared with WT $(p<0.001$; unpaired Student's $t$ test).

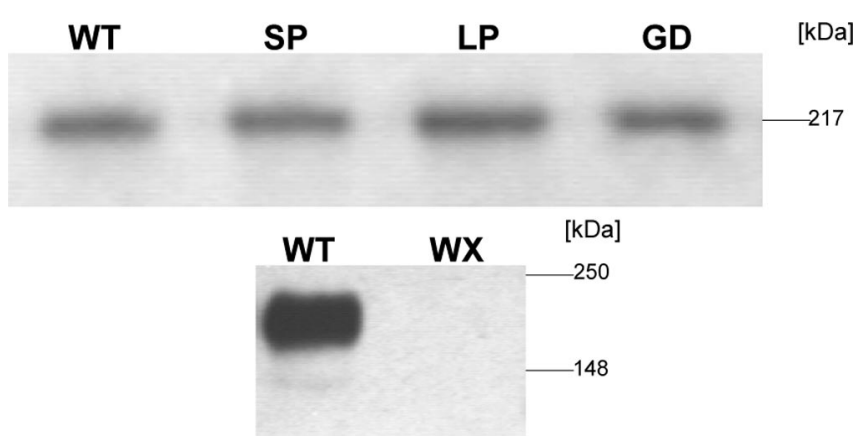

Figure 5. Heterologous expression of $\mathrm{Ca}_{\mathrm{v}} 1.4 \mathrm{WT}$ and different mutant $\alpha 1$ subunits in tsA201 cells. Human embryonic kidney tsA201 cells were transfected with $\mathrm{Ca}_{\mathrm{v}} 1.4$ WT and mutant GD, LP, SP, and WX $\alpha 1$ subunits together with $\beta 3$ and $\alpha 2 \delta 1$ subunit CDNAs, as described in Materials and Methods. $\mathrm{Ca}_{v} 1.4 \alpha 1$ subunit proteins were quantified in immunoblots of microsomal membranes prepared from lysed cells after separation on $8 \%$ SDS-PAGE gels (10 $\mu \mathrm{g}$ of membrane protein per lane) using a generic anti- $\alpha 1$ sequence-directed antibody (anti- $\mathrm{Ca}_{\mathrm{v}} 1.1$ $\alpha 1-1382-1400)$. $\left(\mathrm{a}_{\mathrm{v}} 1.4\right.$ WT and mutants migrated with the expected molecular weight of 219 $\mathrm{kDa}$. Staining was absent for the WX mutant (calculated molecular weight of $161 \mathrm{kDa}$ ). One representative of three experiments yielding similar results is shown.

Stable recordings of $\mathrm{Ca}_{\mathrm{v}} 1.4$-mediated currents were possible over long time periods in oocytes and allowed us to investigate changes of the recovery from inactivation of mutant LP. Note that, because of its very slow inactivation time course, these measurements were not feasible for GD. WT and LP channels were inactivated by $10 \mathrm{sec}$ depolarizing pulses to $V_{\max }$ and then allowed to recover for various time periods before short test pulses to $V_{\max }$ were applied to quantify current recovery. Figure 4 illustrates that, in WT channels, $80 \%$ of $I_{\mathrm{Ca}}$ (Fig. $4 \mathrm{~B}$ ) recovered within $20 \mathrm{sec}$, but only $\sim 50 \%$ of $I_{\mathrm{Ba}}$ recovered within $20 \mathrm{sec}$ (Fig. $4 \mathrm{~A}$ ). Mutation LP significantly slowed recovery with both charge carriers (percentage of recovering current; $I_{\mathrm{Ba}}: \mathrm{WT}, 48.4 \pm 1.8 \%$, $n=9 ; \mathrm{LP}, 31.6 \pm 2.1 \%, n=6 ; p<0.001 ; I_{\mathrm{Ca}}: \mathrm{WT}, 82.4 \pm 1.5 \%$, $n=8 ; \mathrm{LP}, 69.1 \pm 2.0 \%, n=7 ; p<0.001)$.

Because mutants SP and WX did not form functional channels, we investigated the possibility that they reduce expression of the $\alpha 1$ subunit protein. To test this possibility, we transfected tsA-201 cells with all of the mutant constructs and WT together with $\alpha 2 \delta 1$ and $\beta 3$ subunits and measured the expression of $\alpha 1$ protein in Western blots (Fig. 5). No WX $\alpha 1$ protein could be detected, although the epitope of the antibody at the beginning of the C-terminal tail was preserved in this mutant, and cDNA integrity was confirmed by DNA sequencing (see Materials and Methods). In contrast, SP $\alpha 1$ expression was indistinguishable 
from WT, indicating that this mutation does not generally prevent $\alpha 1$ expression. Mutations GD and LP also caused no detectable change in $\alpha 1$ subunit expression.

\section{Discussion}

Although it is widely accepted that disease symptoms of CSNB2 result from a complete loss of $\mathrm{Ca}_{\mathrm{v}} 1.4$ channel function, it remains unclear to which extent channel function must be compromised. Our study therefore focused on structural aberrations still likely to support $\mathrm{Ca}^{2+}$ channel activity. We found that three CSNB2 missense mutations either caused profound changes of $\mathrm{Ca}_{\mathrm{v}} 1.4$ gating or completely prevented channel function. We also report for the first time that the disease can be caused by a mutation (GD) with characteristics that should result in a gain of LTCC function.

GD shifted the voltage dependence of activation to more negative voltages independent of the charge carrier, slowed activation and inactivation kinetics, and removed CDI. All changes should promote $\mathrm{Ca}^{2+}$ entry through the channel. This raises the important question about how increased channel function could impair light-induced signaling between photoreceptors and second-order neurons. In the dark, photoreceptors depolarize to a resting membrane potential of -36 to $-40 \mathrm{mV}$ (Corey et al., 1984; Witkovsky et al., 1997; Schneeweis and Schnapf, 2000; Moriondo et al., 2001), inducing tonic glutamate release. The latter is linearly related to cytoplasmic $\mathrm{Ca}^{2+}$ concentrations and LTCC activity (Witkovsky et al., 1997). Light absorption in the photoreceptor outer segments and closure of cGMP-gated cation channels hyperpolarizes the cells to below $-55 \mathrm{mV}$ (Witkovsky et al., 1997). Because the $V_{0.5 \text {,act }}$ for retinal L-type channels (and $\mathrm{Ca}_{\mathrm{v}}$ 1.4) (Koschak et al., 2003; McRory et al., 2004) is clearly above $-40 \mathrm{mV}$ (Corey et al., 1984; Wilkinson and Barnes, 1996), the retinal operating range of membrane potential changes is at the "foot" of the LTCC $I-V$ curve, and thus $\mathrm{Ca}^{2+}$ influx becomes very small or unmeasurable (Witkovsky et al., 1997) at hyperpolarized voltages maintained during illumination. The pronounced negative shift of the activation curve by the GD mutation must result in a significant increase of $\mathrm{Ca}^{2+}$ influx during illumination. Assuming a $V_{0.5 \text {,act }}$ of $-22 \mathrm{mV}$ and a slope of $4.3 \mathrm{mV}$ for the $I-V$ curve (values measured for retinal $\mathrm{Ca}^{2+}$ channels at physiological $\mathrm{Ca}^{2+}$ concentrations that are close to the parameters found in this study) (Corey et al., 1984), a sigmoidal Boltzmann equation can be used to calculate $I_{\mathrm{Ca}}$ to amount to $4.6 \%$ of maximal current in the dark $(-35 \mathrm{mV})$ and to $0.04 \%$ during illumination $(-55 \mathrm{mV})$. This corresponds to a 100-fold decrease of $I_{\mathrm{Ca}}$ during light exposure. Assuming a shift of $V_{0.5 \text {,act }}$ by the GD mutation by $-20 \mathrm{mV}$ for $I_{\mathrm{Ca}}$ (Table 1), $83 \%$ of $I_{\mathrm{Ca}}$ would be active in the dark and $4.6 \%$ during illumination, corresponding to an 18 -fold decrease. Therefore, the GD mutation would result in an overall increase of $\mathrm{Ca}^{2+}$ entry but at the same time would reduce the dynamic range by almost sixfold. An equivalent change in the dynamic range of tonic glutamate release could then explain how the synaptic gain between first- and second-order neurons is reduced by this mutation.

Our data confirm existing models on the role of S6 segments for channel inactivation and extend them to $\mathrm{Ca}_{\mathrm{v}} 1.4$. Slowing of inactivation by the GD mutation fits with the hypothesis that residues in the pore-lining S6 segments and especially those at their cytoplasmic ends are crucial determinants of slow $\mathrm{Ca}^{2+}$ channel inactivation. GD is located next to a serine residue (Fig. 1) found previously to contribute to the formation of an annular structure on the cytoplasmic end of the channel, which may constrict the cytoplasmic pore opening during inactivation (Shi and
Soldatov, 2002) and/or may serve as a receptor for a gating particle formed by the I-II linker (Stotz et al., 2004). Mutations in the S6 region have also been shown to eliminate CDI of $\mathrm{Ca}_{\mathrm{v}} 1.2$ LTCCs (Shi and Soldatov, 2002). We also found that GD contributes to CDI in $\mathrm{Ca}_{\mathrm{v}} 1.4$. This mutation also shifts $V_{0.5 \text {,act }}$ and affects ion selectivity, suggesting that the negative charge introduced by the GD mutation at the cytoplasmic side of IS6 cannot only affect conformational changes associated with channel activation but can also interfere with cation permeation through the proposed cytoplasmic end of the pore.

Both other missense mutations and the WX truncation induced changes compatible with a loss of function. For LP, we could only record significant currents in the presence of BayK, independent of the expression system used. BayK triggered the appearance of robust L-type currents comparable with WT. Because BayK cannot rapidly recruit channels to the plasma membrane, this may best be explained by a mutation-induced reduction of open probability overcome by BayK. Interestingly, the mutated leucine 1068 is located next to phenylalanine 1069 and very close to serine 1072 (Fig. 1), which were both found to play a critical role for the action of dihydropyridine (DHP) channel activators (Yamaguchi et al., 2003). The LP mutation may thus stabilize a pore conformation that inhibits channel opening. As a result of the low-expression efficiency (see above), single-channel measurements of $\mathrm{Ca}_{\mathrm{v}} 1.4$ channels are difficult. Therefore, future experiments should determine whether mutations of this leucine residue also cause similar changes in other LTCCs more easily accessible to single-channel analysis. The observation that LP supports channel activity in the presence of BayK also has potential therapeutic implications, because $\mathrm{Ca}_{\mathrm{v}} 1.4$ activators may restore activity and improve CSNB2 symptoms. In the case of LP, a complete drug-induced recovery of function is, however, unlikely because of the other gating changes found in our study. For example, LP also significantly slowed the recovery from inactivation, which would favor a decrease in $I_{\mathrm{Ca}}$ caused by the accumulation of channels in inactivated states during cycling between hyperpolarized and depolarized membrane potentials.

Mutations SP and WX did not support $\mathrm{Ca}^{2+}$ channel activity. For WX, this can be explained by the failure to express $\alpha 1$ protein, which is evident from transfected tsA-201 cells. This indicates an important role of the $\mathrm{C}$-terminal tail for proper $\mathrm{Ca}_{\mathrm{v}} 1.4$ protein processing and targeting.

The SP mutation did not reduce $\alpha 1$ protein expression in tsA-201 cells, suggesting that loss of function does not result from an overall failure of $\alpha 1$ protein synthesis. Although it remains to be determined why this mutant fails to support $\mathrm{Ca}^{2+}$ channel activity in oocytes, it is likely that it either prevents $\alpha 1$ subunit targeting to the plasma membrane or obstructs channel gating. The failure of SP to support channel activity emphasizes the important role of this residue for voltage-gated $\mathrm{Ca}^{2+}$ channel function. Accordingly, a mutation of this conserved serine residue in $\mathrm{Ca}_{\mathrm{v}} 2.1$ channels also results in human pathology (severe forms of FHM1) (Kors et al., 2001).

Our data for GD and WX differ from a previous report (McRory et al., 2004) in which neither the pronounced negative shift of the $I-V$ curve nor changes in inactivation were observed. Only a minimal (but statistically significant) change in the slope of activation and a less pronounced shift of the half-activation potential to more positive voltages with $\mathrm{Ca}^{2+}$ compared with $\mathrm{Ba}^{2+}$ as charge carrier were found. We ruled out the idea that differences in the expression system account for this discrepancy. McRory et al. (2004) also found normal current amplitudes and 
gating kinetics for mutant WX. One possible explanation is the structural differences in the $\mathrm{Ca}_{\mathrm{v}} 1.4 \alpha 1$ subunits used to study the mutations. The construct used by McRory et al. (2004) differs from ours in four positions ( $\mathrm{K}$ vs $\mathrm{R}$ in position 58 , $\mathrm{E}$ vs $\mathrm{G}$ in position 380, $\mathrm{R}$ vs $\mathrm{H}$ in position 1282 , and I vs $\mathrm{V}$ in position 1306 ). These residues are highly conserved among LTCCs and nonLTCCs (alignments not shown) and may represent so far unknown [National Center for Biotechnology Information (NCBI) GenBank and Ensembl databases] polymorphisms of CACNA1F. Interestingly, the G369D mutation affects a glycine residue localized in a very conserved region at the cytoplasmic end of IS6 and introduces a negative charge. As mentioned previously, the construct used by McRory et al. (2004) contains a glycine residue replacing a glutamate residue at position 380 . The absence of this negative charge close to the G369D mutation may prevent an electrostatic interaction between the D369 and the E380 residue, which can occur in our mutant GD but not in McRory's mutant GD construct nor in their, or our, WT Ca $1.4 \alpha 1$. It will therefore be interesting to test in future experiments whether this electrostatic interaction can indeed affect channel gating. In addition, their construct represents a different splice variant and contains an 11 amino acid insertion in the I-II linker and a seven amino acid deletion in the domain IVS3-IVS4. Additional experiments must also test the interesting possibility that alternative splicing or single-nucleotide polymorphisms can affect the phenotype of CSNB2 mutations.

McRory et al. (2004) also analyzed mutants G674D and A928D (G663D and A917D in our $\mathrm{Ca}_{\mathrm{v}} 1.4 \alpha 1$ construct) and found no evidence for gating changes in tsA-201 cells. Similarly, we found no gating changes for mutations R508Q and L1368H, but both caused a decrease of $\alpha 1$ subunit synthesis in tsA-201 cells $(n=3$; data not shown). We are currently investigating the consequences of decreased protein expression on current density in different expression systems.

$\mathrm{Ca}_{\mathrm{v}} 1.4 \alpha 1$ subunits also occur in immune cells, such as in mast and plasma cells (McRory et al., 2004). Based on our findings, immune cells from patients carrying the CSNB2 mutations analyzed here may provide novel probes to study the role of $\mathrm{Ca}_{\mathrm{v}} 1.4$ in the human immune system.

\section{References}

Ball SL, Powers PA, Shin HS, Morgans CW, Peachey NS, Gregg RG (2002) Role of the $\beta 2$ subunit of voltage-dependent calcium channels in the retinal outer plexiform layer. Invest Ophthalmol Vis Sci 43:1595-1603.

Barnes S, Kelly ME (2002) Calcium channels at the photoreceptor synapse. Adv Exp Med Biol 514:465-476.

Baumann L, Gerstner A, Zong X, Biel M, Wahl-Schott C (2004) Functional characterization of the L-type $\mathrm{Ca}^{2+}$ channel $\mathrm{Ca}_{\mathrm{v}} 1.4 \alpha 1$ from mouse retina. Invest Ophthalmol Vis Sci 45:708-713.

Bech-Hansen NT, Naylor MJ, Maybaum TA, Pearce WG, Koop B, Fishman GA, Mets M, Musarella MA, Boycott KM (1998) Loss-of-function mutations in a calcium-channel $\alpha 1$-subunit gene in Xp11.23 cause incomplete X-linked congenital stationary night blindness. Nat Genet 19:264-267.

Boycott KM, Pearce WG, Bech-Hansen NT (2000) Clinical variability among patients with incomplete X-linked congenital stationary night blindness and a founder mutation in CACNA1F. Can J Ophthalmol 35:204-213.

Castellano A, Wei X, Birnbaumer L, Perez-Reyes E (1993) Cloning and expression of a third calcium channel $\beta$ subunit. J Biol Chem 268:3450-3455.

Catterall WA (2000) Structure and regulation of voltage-gated $\mathrm{Ca}^{2+}$ channels. Annu Rev Cell Dev Biol 16:521-555.

Corey DP, Dubinsky JM, Schwartz EA (1984) The calcium current in inner segments of rods from the salamander (Ambystoma tigrinum) retina. J Physiol (Lond) 354:557-575.
Ellis SB, Williams ME, Ways NR, Brenner R, Sharp AH, Leung AT, Campbell KP, McKenna E, Koch WJ, Hui A, Schwartz A, Harpold MM (1988) Sequence and expression of mRNAs encoding the $\alpha 1$ and $\alpha 2$ subunits of a DHP-sensitive calcium channel. Science 241:1661-1664.

Hess P, Lansman JB, Tsien RW (1986) Calcium channel selectivity for divalent and monovalent cations. Voltage and concentration dependence of single channel current in ventricular heart cells. J Gen Physiol 88:293-319.

Horton RM, Hunt HD, Ho SN, Pullen JK, Pease LR (1989) Engineering hybrid genes without the use of restriction enzymes: gene splicing by overlap extension. Gene 77:61-68.

Huber I, Wappl E, Herzog A, Mitterdorfer J, Glossmann H, Langer T, Striessnig J (2000) Conserved $\mathrm{Ca}^{2+}$ antagonist binding properties and putative folding structure of a recombinant high affinity dihydropyridine binding domain. Biochem J 347:829-836.

Kors EE, Terwindt GM, Vermeulen FL, Fitzsimons RB, Jardine PE, Heywood P, Love S, van den Maagdenberg AM, Haan J, Frants RR, Ferrari MD (2001) Delayed cerebral edema and fatal coma after minor head trauma: role of the CACNA1A calcium channel subunit gene and relationship with familial hemiplegic migraine. Ann Neurol 49:753-760.

Koschak A, Reimer D, Walter D, Hoda JC, Heinzle T, Grabner M, Striessnig J (2003) $\mathrm{Ca}_{\mathrm{v}} 1.4 \alpha 1$ subunits can form slowly inactivating dihydropyridinesensitive L-type $\mathrm{Ca}^{2+}$ channels lacking $\mathrm{Ca}^{2+}$-dependent inactivation. J Neurosci 23:6041-6049.

Krieg PA, Melton DA (1984) Functional messenger RNAs are produced by SP6 in vitro transcription of cloned cDNAs. Nucleic Acids Res 12:7057-7070.

Liang H, DeMaria CD, Erickson MG, Mori MX, Alseikhan BA, Yue DT (2003) Unified mechanisms of $\mathrm{Ca}^{2+}$ regulation across the $\mathrm{Ca}^{2+}$ channel family. Neuron 39:951-960.

McRory JE, Hamid J, Doering CJ, Garcia E, Parker R, Hamming K, Chen L, Hildebrand M, Beedle AM, Feldcamp L, Zamponi GW, Snutch TP (2004) The CACNA1F gene encodes an L-type calcium channel with unique biophysical properties and tissue distribution. J Neurosci 24:1707-1718.

Morgans CW (2000) Neurotransmitter release at ribbon synapses in the retina. Immunol Cell Biol 78:442-446.

Morgans CW, Gaughwin P, Maleszka R (2001) Expression of the $\alpha 1 \mathrm{~F} \mathrm{cal-}$ cium channel subunit by photoreceptors in the rat retina. Mol Vis 7:202-209.

Moriondo A, Pelucchi B, Rispoli G (2001) Calcium-activated potassium current clamps the dark potential of vertebrate rods. Eur J Neurosci $14: 19-26$

Murakami M, Nakagawasai O, Fujii S, Kameyama K, Murakami S, Hozumi S, Esashi A, Taniguchi R, Yanagisawa T, Tan-no K, Tadano T, Kitamura K, Kisara K (2001) Antinociceptive action of amlodipine blocking N-type $\mathrm{Ca}^{2+}$ channels at the primary afferent neurons in mice. Eur J Pharmacol 419:175-181.

Perez-Reyes E, Castellano A, Kim HS, Bertrand P, Baggstrom E, Lacerda AE, Wei X, Birnbaumer L (1992) Cloning and expression of a cardiac/brain $\beta$ subunit of the L-type calcium channel. J Biol Chem 267:1792-1797.

Platzer J, Engel J, Schrott-Fischer A, Stephan K, Bova S, Chen H, Zheng H, Striessnig J (2000) Congenital deafness and sinoatrial node dysfunction in mice lacking class D L-type calcium channels. Cell 102:89-97.

Safayhi H, Haase H, Kramer U, Bihlmayer A, Roenfeldt M, Ammon HP, Froschmayr M, Cassidy TN, Morano I, Ahlijanian M, Striessnig J (1997) L-type calcium channels in insulin-secreting cells: biochemical characterization and phosphorylation in RINm5F cells. Mol Endocrinol 11:619-629.

Schneeweis DM, Schnapf JL (2000) Noise and light adaptation in rods of the macaque monkey. Vis Neurosci 17:659-666.

Shi C, Soldatov NM (2002) Molecular determinants of voltage-dependent slow inactivation of the $\mathrm{Ca}^{2+}$ channel. J Biol Chem 277:6813-6821.

Splawski I, Timothy KW, Sharpe LM, Decher N, Kumar P, Bloise R, Napolitano C, Schwartz PJ, Joseph RM, Condouris K, Tager-Flusberg H, Priori SG, Sanguinetti MC, Keating MT (2004) $\mathrm{Ca}_{\mathrm{v}} 1.2$ calcium channel dysfunction causes a multisystem disorder including arrhythmia and autism. Cell 119:19-31.

Stotz SC, Jarvis SE, Zamponi GW (2004) Functional roles of cytoplasmic loops and pore lining transmembrane helices in the voltage-dependent inactivation of HVA calcium channels. J Physiol (Lond) 554:263-273.

Strom TM, Nyakatura G, Apfelstedt-Sylla E, Hellebrand H, Lorenz B, Weber 
BH, Wutz K, Gutwillinger N, Ruther K, Drescher B, Sauer C, Zrenner E, Meitinger T, Rosenthal A, Meindl A (1998) An L-type calcium-channel gene mutated in incomplete X-linked congenital stationary night blindness. Nat Genet 19:260-263.

Tremblay F, Laroche RG, De Becker I (1995) The electroretinographic diagnosis of the incomplete form of congenital stationary night blindness. Vision Res 35:2383-2393.

Wheeler DB, Tsien RW, Randall A (1994) Identification of calcium channels that control neurosecretion. Science 266:828-831.

Wilkinson MF, Barnes S (1996) The dihydropyridine-sensitive calcium channel subtype in cone photoreceptors. J Gen Physiol 107:621-630.

Witkovsky P, Schmitz Y, Akopian A, Krizaj D, Tranchina D (1997) Gain of rod to horizontal cell synaptic transfer: relation to glutamate release and a dihydropyridine-sensitive calcium current. J Neurosci 17:7297-7306.

Yamaguchi S, Zhorov BS, Yoshioka K, Nagao T, Ichijo H, Adachi-Akahane S (2003) Key roles of Phe1112 and Ser1115 in the pore-forming IIIS5-S6 linker of L-type $\mathrm{Ca}^{2+}$ channel $\alpha 1 \mathrm{C}$ subunit $\left(\mathrm{Ca}_{\mathrm{v}} 1.2\right)$ in binding of dihydropyridines and action of $\mathrm{Ca}^{2+}$ channel agonists. Mol Pharmacol 64:235-248.

Yang J, Ellinor PT, Sather WA, Zhang JF, Tsien RW (1993) Molecular determinants of $\mathrm{Ca}^{2+}$ selectivity and ion permeation in L-type $\mathrm{Ca}^{2+}$ channels. Nature 366:158-161.

Zamponi GW (2003) Regulation of presynaptic calcium channels by synaptic proteins. J Pharmacol Sci 92:79-83. 